\title{
ALLEVIATING EFFECTS OF ASCORBIC ACID ON LEAD TOXICITY IN GOJI (Lycium barbarum L.) IN VITRO
}

\section{ŁAGODZENIE SKUTKÓW TOKSYCZNEGO DZIAŁANIA OŁOWIU POPRZEZ ZASTOSOWANIE DODATKU KWASU ASKORBINOWEGO W KULTURACH IN VITRO GOJI (Lycium barbarum L.)}

\author{
Department of Plant Genetics, Breeding and Biotechnology, West Pomeranian University \\ of Technology, Szczecin, Poland \\ 1Department of Horticulture, West Pomeranian University of Technology, Szczecin, Poland \\ 2Department of Plant Physiology and Biochemistry, West Pomeranian University \\ of Technology, Szczecin, Poland
}

\begin{abstract}
Streszczenie. Ołów jest jednym z najczęściej występujących metali ciężkich w środowisku. Celem badań było określenie wpływu działania egzogennego $1 \mathrm{mM}$ kwasu askorbinowego na wzrost i parametry biochemiczne Lycium barbarum w warunkach stresu wywołanego $1 \mathrm{mM} \mathrm{Pb}\left(\mathrm{NO}_{3}\right)_{2} \mathrm{w}$ kulturach in vitro. Eksplantaty stanowiły fragmenty pędów z pakami kątowymi. $\mathrm{Na}$ podstawie otrzymanych wyników badań stwierdzono, że ołów miał negatywny wpływ na cechy morfologiczne, takie jak długość pędu i korzeni eksplantatów goji. Dodatek do pożywki soli $\mathrm{Pb}\left(\mathrm{NO}_{3}\right)_{2}$ spowodował spadek zawartości chlorofili i karotenoidu, peroksydację lipidów, a także znacznie wpłynął na akumulację proliny w liściach goji. Dodatek do pożywki MS $1 \mathrm{mM}$ kwasu askorbinowego łagodził skutki działania soli ołowiu na wzrost i rozwój eksplantatów goji, zawartość MDA i proliny. Obecność kwasu askorbinowego w podłożu, w warunkach stresu wywołanego przez $\mathrm{Pb}\left(\mathrm{NO}_{3}\right)_{2}$, miała pozytywny wpływ na świeżą i suchą masę roślin, ale nie wpływała istotnie na zawartość wody w roślinie.
\end{abstract}

Key words: abiotic stress, goji, heavy metal stress, micropropagation, $\mathrm{Pb}\left(\mathrm{NO}_{3}\right)_{2}$.

Słowa kluczowe: goji, stres metali ciężkich, mikrorozmnażanie, $\mathrm{Pb}\left(\mathrm{NO}_{3}\right)_{2}$, stres abiotyczny.

\section{INTRODUCTION}

Heavy metal contamination in soil could result in inhibition of plant growth and yield reduction, and even pose a great to human health via food chain through the accumulation by plants (Nagajyoti et al. 2010; Lamhamdi et al. 2011; Qiao et al. 2015; Sędzik et al. 2015; Nowakowska et al. 2017). Lead (Pb) is one of the dangerous heavy metal pollutants of the environment that originates from various sources. Its contamination results from mining and smelting activities, lead containing paints, paper and pulp, gasoline and explosives as well as from the disposal of municipal sewage sludge enriched with lead (Boroumand Jazi et al. 2011; Lamhamdi et al. 2013; Qiao et al. 2015). As many of the Pb pollutants are indispensable for

Corresponding author - Adres do korespondencji: Marcelina Krupa-Małkiewicz, Department of Plant Genetics, Breeding and Biotechnology, West Pomerania University of Technology, Szczecin, Juliusza Słowackiego 17, 71-434 Szczecin, Poland, e-mail: mkrupa@zut.edu.pl 
modern human life, soil contamination with $\mathrm{Pb}$ is not likely to decrease in the near future (Sharma and Dubney 2005). Lead is taken up by plants mainly through the root system and partly in minor amounts through the leaves (Boroumand Jazi et al. 2011). The effect of lead depends on the concentration, type of salt, soil properties and plant species (Lamhamdi et al. 2011). According to Ruley et al. (2004) and Boroumand Jazi et al. (2011) a concentration of $\mathrm{Pb}$ higher than $30 \mathrm{ppm}$ in plant tissue is toxic for most of species. Lead can cause a broad range of physiological and biochemical dysfunctions (Lamhamdi et al. 2013). The steadily increasing levels of this metal in the environment causes yellowing of young leaves, reduction in absorption of essential elements such as iron and reduction in the rate of photosynthesis (Sharma and Dubey 2005). High lead concentration affected seed germination, seedlings growth, tolerance index, dry mass of roots and shoots. Although photosynthesis is usually limited, chlorophyll and carotenoid contents, photosynthetic rate and $\mathrm{CO}_{2}$ assimilation are strongly decreased (Yang et al. 2011; Qiao et al. 2015). Increase of lead in plant tissue causing production of reactive oxygen species (ROS), and changes in lipid membrane structure and permeability (Sharma and Dubney 2005; Najeeb et al 2017).

A possible survival strategy for plants under heavy metal conditions is to use some compounds that could alleviate the $\mathrm{Pb}\left(\mathrm{NO}_{3}\right)_{2}$ stress effect. The use of vitamins as antioxidants mediated heavy metal tolerance as a selection factor as well as a driving force for improving resistance and adaptation to many abiotic stress factors (Azooz et al. 2013). Vitamins are required in trace amount to maintain normal growth and proper development of all organisms. In addition, vitamins are cofactors of many metabolic reactions (Abdelhamid et al. 2013). Vitamin supplements are known to enhance the plant activities and did not have toxic or mutagenic action (Hassanein et al. 2009; Azooz et al. 2013). Ascorbic acid is an organic acid with an antioxidant properties. The protective role of ascorbic acid in plant cells from the adverse effects of salinity stress was described by Younis et al. (2010) in Vicia faba seedlings, Bybordi (2012) in canola, Krupa-Małkiewicz et al. (2015) in tomato seedlings. The role of vitamins in modifying the environmental stresses induced changes in osmoprotectant contents was also investigated by Sadak et al. (2010) and Abdelhamid et al. (2013). According to Krupa-Małkiewicz et al. (2015) ascorbic acid may be of value within biotechnology for the production of valuable substances as well as plant protection.

Lycium barbarum $\mathrm{L}$. is commonly known as goji berry. These perennial shrubs inhabiting arid and semiarid regions of Asia, America and Africa. Their special physiological characteristics of drought-resistance and salt-resistance make them a suitable plant to prevent land desertification and alleviating the degree of soil salinity, which is very important for an ecosystem and agriculture in the remote areas (Zheng et al. 2011; Dimitrova et al. 2016).

The objective of this work was to investigate whether ascorbic acid could be a protectant to ameliorate the influence of lead stress on goji explants in in vitro culture.

\section{MATERIAL AND METHODS}

Culture condition and treatments. The plants material consisted of $15-20 \mathrm{~mm}$ shoots with auxiliary buds of goji 'A' (Lycium barbarum L.) obtained from sterile stabilized in vitro culture. The explants were multiplied on the MS medium according to Murashige and Skoog (1962) composition of vitamins, macro- and microelements, 3\% (w/v) sucrose (Chempur, Poland), $0.8 \%(\mathrm{w} / \mathrm{v})$ agar (Biocorp, Poland) and $100 \mathrm{mg} \cdot \mathrm{dm}^{-3}$ myo-inositol 
(Duchefa Biochemie, Netherlands). After 35 days, shoots cuttings were placed on MS medium supplemented with $1 \mathrm{mM}$ ascorbic acid (ASA), $1 \mathrm{mM} \mathrm{Pb}\left(\mathrm{NO}_{3}\right)_{2}$ or $1 \mathrm{mM}$ ASA with $1 \mathrm{mM} \mathrm{Pb}\left(\mathrm{NO}_{3}\right)_{2}$. MS medium without addition of ascorbic acid and $\mathrm{Pb}\left(\mathrm{NO}_{3}\right)_{2}$ salt solution was the control. After 28 days, morphological (shoot and root length, number of root per one explant, fresh and dry mass) and biochemical parameters (MDA, proline, Chl a, Chl $b$, Car), as well as plant water content were measured. Dry mass of explants was determined after drying in the hot-air oven at $70^{\circ} \mathrm{C}$ for $24 \mathrm{~h}$. Plant water content (PWC\%) was determined following Equations 1:

PWC $(\%)=($ fresh mass - dry mass/fresh mass $) \times 100$

The $\mathrm{pH}$ of all the medium was adjusted to 5.8 . Culture jars $(300 \mathrm{ml})$ with the medium (30 $\mathrm{ml}$ ) were autoclaved for 20 minutes at $121^{\circ} \mathrm{C}$ and $0.1 \mathrm{MPa}$. Sample size was 4 explants per culture vessel with eight replicates per treatment. All cultures were incubated in growth room at a temperature of $25^{\circ} \mathrm{C}$ under 16 hours photoperiod with a photosynthetic photon flux density (PPFD) of $40 \mu \mathrm{mol} \cdot \mathrm{m}^{-2} \cdot \mathrm{s}^{-1}$.

Determination of malondialdehyde. The level of peroxidation was measured in terms of malondialdehyde (MDA) (a product of lipid peroxidation) content determined by the thiobarbituric acid (TBA) according to Sudhakar $i$ in. (2001). Plant tissue was homogenized in $5 \mathrm{~cm}^{3}$ of $0.1 \%$ trichloroacetic acid (TCA). The homogenate was centrifuged for $15 \mathrm{~min}$ and $4.0 \mathrm{~cm}^{3}$ of $20 \%$ TCA containing $0.5 \%$ TBA was added. The mixture was heated at $95^{\circ} \mathrm{C}$ for $30 \mathrm{~min}$ and then quickly cooled on ice bath. The concentration of MDA was calculated from the absorbance at 600, 532 and $450 \mathrm{~nm}$, and MDA contents were estimated using the following Equations 2:

$\operatorname{MDA}\left(\mu \mathrm{mol} \cdot \mathrm{g}^{-1} \mathrm{fm}\right)=\left[6.45 \times\left(A_{532}-A_{600}\right)-0.56 A_{450}\right] \times \mathrm{V} / \mathrm{fm}$ where:

$V$ - volume of the sample,

$A$ - absorbance,

$\mathrm{fm}$ - fresh mass.

Determination of proline. Proline contents was measured according to the method described by Bates et al. (1973). Fresh seedlings $(0.5 \mathrm{~g})$ were ground in $3 \%(\mathrm{v} / \mathrm{v})$ aqueous sulphosalicylic acid and proline were estimated by ninhydrin reagent. The absorbance of the fraction with toluene aspired from the liquid phase was read at $520 \mathrm{~nm}$. The proline concentration was expressed in $\mu \mathrm{mol} \cdot \mathrm{g}^{-1}$ fresh mass.

Determination of pigments content. The levels of Chlorophyll $a, b$ and carotenoid (Car) were measured in $80 \%(\mathrm{v} / \mathrm{v})$ acetone extracts. Chlorophyll $a, b$ and carotenoid content was determined spectrophotometrically at 663,645 and $440 \mathrm{~nm}$. The concentration of $\mathrm{Chl}$ a and Chl $b$ were calculated according to Arnon et al. (1956) in modification to Lichtenthaler and Wellburn (1983) from Equations 3 and 4, respectively derived by Hendry and Grime (1993).

$$
\begin{aligned}
& \text { chlorophyll } a\left(\mathrm{mg} \cdot \mathrm{g}^{-1} \mathrm{fm}\right)=\left[\left(12.7 A_{663}-2.69 A_{645}\right) / 1,000 \times \mathrm{fm}\right] \times V \\
& \text { chlorophyll } b\left(\mathrm{mg} \cdot \mathrm{g}^{-1} \mathrm{fm}\right)=\left[\left(22.9 A_{645}-4.68 A_{663}\right) / 1,000 \times \mathrm{fm}\right] \times V
\end{aligned}
$$

Carotenoid content was determined by the Equation 5 of Price and Henry (1991): 
carotenoid $\left(\mathrm{mg} \cdot \mathrm{g}^{-1} \mathrm{fm}\right)=\left[\left(A_{480}+0.114 A_{663}\right)-\left(0.638 A_{663}\right) \times \mathrm{V} / 112.5 \times \mathrm{fm}\right]$ where:

$V$ - volume of the sample,

$A$ - absorbance,

fm - fresh mass.

Statistical analysis. Results obtained in in vitro cultures were statistically analysed using the Statistica v. 12 software. The significance of differences was determined by means of variance analysis (ANOVA) and Tukey's test, at the level of significance of $\alpha<0.05$. Proline, MDA, Chl $a$, Chl $b$ and Car were measured in triplicates for each experimental combination.

\section{RESULTS AND DISCUSSION}

Effect of lead on plant growth. In this work, we analysed the possible role of exogenous nicotinamide treatment to alleviate the negative influence of $\mathrm{Pb}\left(\mathrm{NO}_{3}\right)_{2}$ stress factor. $\mathrm{Pb}$ stress induced plant growth inhibition has been well describe by many researchers (Ruley et al. 2004; Boroumand Jazi et al. 2011; Yang et al. 2011; Lamhamdi et al. 2013; Sędzik et al. 2015; Qiao et al. 2015). In the current study, shoot and root length, number of roots per one goji explant were significantly decreased at $1 \mathrm{mM} \mathrm{Pb}\left(\mathrm{NO}_{3}\right)_{2}$ treatment compared to control (Table 1, Fig. 1). Addition to MS medium $1 \mathrm{mM}$ ascorbic acid with $1 \mathrm{mM} \mathrm{Pb}\left(\mathrm{NO}_{3}\right)_{2}$ increased the goji shoot and root length by $31 \%$ and $74.5 \%$, respectively, compare to lead treatment explants. The most significant changes were observed in case of number of roots. It was noticed that heavy metal stress significantly decreased the number of roots and addition to MS medium $1 \mathrm{mM}$ ascorbic acid with or without lead had positive effect (Table 1).

Table 1. The influence of $1 \mathrm{mM}$ ascorbic acid and $1 \mathrm{mM} \mathrm{Pb}\left(\mathrm{NO}_{3}\right)_{2}$ on shoot and root length and number of roots of goji (Lycium barbarum L.) in vitro

Tabela 1. Wpływ $1 \mathrm{mM}$ kwasu askorbinowego (ASA) i $1 \mathrm{mM} \mathrm{Pb}\left(\mathrm{NO}_{3}\right)_{2}$ na długość pędu i korzeni oraz liczbę korzeni goji (Lycium barbarum L.) w kulturach in vitro

\begin{tabular}{|c|c|c|c|}
\hline \multirow[b]{2}{*}{$\begin{array}{l}\text { Medium } \\
\text { Pożywka }\end{array}$} & \multicolumn{3}{|c|}{$\begin{array}{l}\text { Morphological traits } \\
\text { Cechy morfologiczne }\end{array}$} \\
\hline & $\begin{array}{l}\text { shoot length } \\
\text { długość pędu } \\
\text { [cm] }\end{array}$ & $\begin{array}{c}\text { root length } \\
\text { długość korzenia } \\
{[\mathrm{cm}]}\end{array}$ & $\begin{array}{c}\text { number of roots per } \\
\text { one explant } \\
\text { liczba korzeni na } \\
\text { jednym eksplantacie }\end{array}$ \\
\hline MS & 5.45 a & $3.27 \quad a$ & $1.36 \mathrm{bc}$ \\
\hline $\mathrm{MS}+1 \mathrm{mM}$ ASA & 5.25 a & $4.07 \quad \mathrm{a}$ & $1.72 a b$ \\
\hline $\mathrm{MS}+1 \mathrm{mM} \mathrm{Pb}\left(\mathrm{NO}_{3}\right)_{2}$ & $3.06 \mathrm{c}$ & $2.00 \mathrm{~b}$ & $1.27 \mathrm{C}$ \\
\hline $\mathrm{MS}+1 \mathrm{mM} \mathrm{ASA}+1 \mathrm{mM} \mathrm{Pb}\left(\mathrm{NO}_{3}\right)_{2}$ & $4.00 \mathrm{~b}$ & 3.49 a & $2.0 \quad a$ \\
\hline Mean - Średnia & 4.44 & 3.2 & 1.58 \\
\hline
\end{tabular}

MS - Murashige and Skoog (1962) medium - pożywka wg składu Murashige and Skoog (1962), ASA - ascorbic acid - kwas askorbinowy.

Letters $(a-c)$ indicate significant differences between medium. Means in the same column followed by the same letter are not significantly different $(\alpha<0.05)$ - Litery $(a-c)$ oznaczają istotne różnice między rodzajami pożywek. Średnie oznaczone tymi samymi literami alfabetu nie różnią się istotnie $(\alpha<0.05)$. 


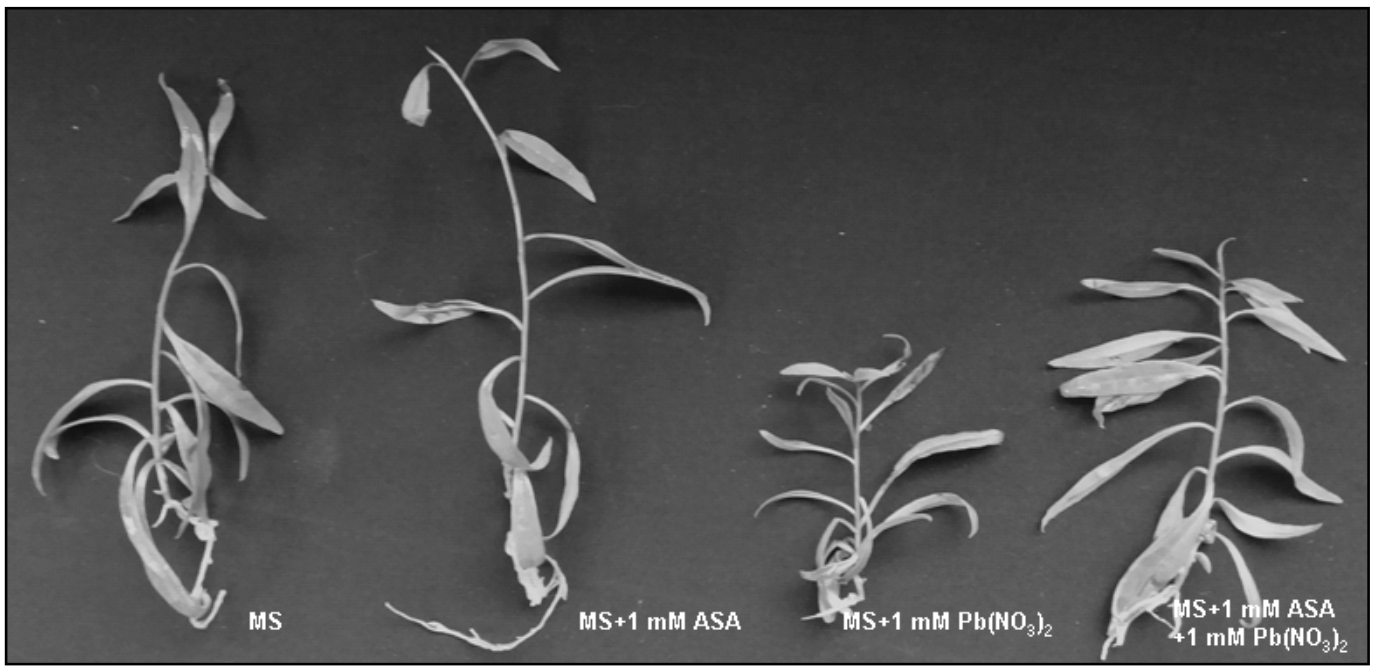

Fig. 1. Influence of $1 \mathrm{mM}$ ascorbic acid with or without $1 \mathrm{mM} \mathrm{Pb}\left(\mathrm{NO}_{3}\right)_{2}$ on micropropagation of goji (Lycium barbarum L.)

Ryc. 1. Wpływ $1 \mathrm{mM}$ kwasu askorbinowego z $1 \mathrm{mM} \mathrm{Pb}\left(\mathrm{NO}_{3}\right)_{2}$ lub bez tego dodatku na mikrorozmnażanie goji (Lycium barbarum L.)

Moreover, goji grown in the MS medium supplemented with $1 \mathrm{mM}$ ASA and $1 \mathrm{mM}$ $\mathrm{Pb}\left(\mathrm{NO}_{3}\right)_{2}$ developed the highest number of roots per one explants (2.0). Similar reduction in growth performance were found in wheat in response to $3 \mathrm{mM} \mathrm{Pb}\left(\mathrm{NO}_{3}\right)_{2}$ (Lamhamdi et al. 2011). Also Boroumand Jazi et al. (2001) showed that increased concentration of $\mathrm{Pb}\left(\mathrm{NO}_{3}\right)_{2}$ in the medium from 0 to $2 \mathrm{mM}$ decreased length of root and stem of Brassica napus var. Okapi as compared to the control. According to Nagajyoti et al. (2010) the degree to which root elongation is inhibited depends upon the concentration of lead and ionic composition and $\mathrm{pH}$ of the medium. Inhibitory effects of lead on growth and biomass production may possibly derived from its inhibitory effect on cell division or cell expansion in the elongation zone or both of them reduce root length (Nagajyoti et al. 2010; Boroumand Jazi et al. 2011).

Effect of lead on fresh and dry mass and PWC. Exposure of the goji explants to $1 \mathrm{mM} \mathrm{Pb}\left(\mathrm{NO}_{3}\right)_{2}$ markedly reduced fresh and dry mass by $53 \%$ and $52 \%$, respectively, compared with control (Table 2).

Table 2. The influence of $1 \mathrm{mM}$ ascorbic acid and $1 \mathrm{mM} \mathrm{Pb}\left(\mathrm{NO}_{3}\right)_{2}$ on fresh and dry mass and plant water content in goji (Lycium barbarum L.) in in vitro culture

Tabela 2. Wpływ 1 mM kwasu askorbinowego (ASA) i $1 \mathrm{mM} \mathrm{Pb}\left(\mathrm{NO}_{3}\right)_{2}$ na świeżą i suchą masę oraz zawartość wody w roślinie goji (Lycium barbarum L.) namnażanej w kulturach in vitro

\begin{tabular}{|c|c|c|c|}
\hline $\begin{array}{l}\text { Medium } \\
\text { Pożywka }\end{array}$ & $\begin{array}{c}\text { Fresh mass } \\
\text { Świeża masa } \\
{[\mathrm{g}]}\end{array}$ & $\begin{array}{c}\text { Dry mass } \\
\text { Sucha masa } \\
{[\mathrm{g}]}\end{array}$ & $\begin{array}{c}\text { Plant Water Content } \\
\text { Zawartość wody } \\
\text { w roślinie } \\
{[\%]}\end{array}$ \\
\hline MS & $0.248 a^{*}$ & $0.025 \mathrm{~b}$ & 89.92 \\
\hline $\mathrm{MS}+1 \mathrm{mM}$ ASA & $0.288 \quad a$ & $0.033 \quad a$ & 88.54 \\
\hline $\mathrm{MS}+1 \mathrm{mM} \mathrm{Pb}\left(\mathrm{NO}_{3}\right)_{2}$ & 0.117 & 0.012 & 89.74 \\
\hline $\mathrm{MS}+1 \mathrm{mM} \mathrm{ASA}+1 \mathrm{mM} \mathrm{Pb}\left(\mathrm{NO}_{3}\right)_{2}$ & $0.250 \quad a$ & 0.024 & 90.40 \\
\hline
\end{tabular}

Explanations see Table 1 - Objaśnienia zob. tab. 1. 
Addition to MS medium $1 \mathrm{mM}$ ASA with $1 \mathrm{mM} \mathrm{Pb}\left(\mathrm{NO}_{3}\right)_{2}$ greatly relieved $\mathrm{Pb}$-induced reduction in fresh and dry mass and the values returned close to control. Furthermore, the use of ascorbic acid under non-stress condition caused increased in fresh and dry mass and the value were even higher than control by $16 \%$ and $32 \%$, respectively. No effect was detected in ASA with or without $\mathrm{Pb}\left(\mathrm{NO}_{3}\right)_{2}$ treatment on plant water content of goji explants.

According to many authors (Munns 2005; Tuna et al. 2008; Piwowarczyk et al. 2016), one of the assessment method to determine the influence of stress factor on plants should be evaluation of plants dry mass. Therefore, it is believed that increased tolerance to stress factor can be associated with increase or unchanged dry mass content in plants from stressed and control conditions. A similar negative effect of $\mathrm{Pb}$ on the reduction of fresh and dry mass by $28 \%$ and $29 \%$, respectively, at $15 \mathrm{mM} \mathrm{Pb}$ was observed by Lamhamdi et al. (2013) in spinach. According to mentioned authors these symptoms can be essentially attributed to a deficiency of macroelements, which results from an inhibition of their uptake under stress factor. Similar results about the inhibitory effects of salt stress in the plant Lycium barbarum and Lycium chinense have been reported (Dimitrova et al. 2016). Boroumand Jazi et al. (2011) showed that the fresh and dry mass of Brassica napus roots was significantly decrease as plants received $\mathrm{Pb}$ in the nutrient solution. However, $10 \mu \mathrm{M}$ salicylic acid significantly increased the fresh mass of root and shoot as compare with lead treatment. Inhibition in plant fresh and dry mass under cadmium stress was significant alleviated by exogenous application of biologically active substances such as glutathione (GSH), glycinebetaine (GB), brassinosteroids (BRs), salicylic acid (SA) treatment in Oryza sativa (Cao et al. 2013).

Effect of $\mathrm{Pb}\left(\mathrm{NO}_{3}\right)_{2}$ on chlorophyll $a$ and $\boldsymbol{b}$ and carotenoid content. Measurement of chlorophylls contents, which has been shown to correlate negatively with mineral uptake, is commonly used method to monitor oxidative stress in plants (Ruley et al. 2004). The inhibition of chlorophyll synthesis by heavy metals is often manifesting as chlorosis. The change in chlorophyll structure may indicate that absorption of $\mathrm{Pb}$ was higher than essential mineral ions, especially magnesium (Akinci et al. 2010). In the present study, exposure of the goji explants to $1 \mathrm{mM} \mathrm{Pb}\left(\mathrm{NO}_{3}\right)_{2}$ markedly reduced $\mathrm{Chl} a$ and $b$ and Car contents by $21 \%$, $51 \%$ and $54 \%$, respectively, compared with control (Table 3).

Table 3. The influence of $1 \mathrm{mM}$ ascorbic acid and $1 \mathrm{mM} \mathrm{Pb}\left(\mathrm{NO}_{3}\right)_{2}$ on chlorophyll a $(\mathrm{Chl} a)$ and $b$ $(\mathrm{Chl} b)$ and carotenoid (Car) content in leaves of goji (Lycium barbarum L.) in in vitro culture

Tabela 3.Wpływ $1 \mathrm{mM}$ kwasu askorbinowego i $1 \mathrm{mM} \mathrm{Pb}\left(\mathrm{NO}_{3}\right)_{2}$ na zawartość chlorofilu a $(\mathrm{Chl} a)$ i $b$ (Chl b) oraz karotenoidu (Car) w liściach goji (Lycium barbarum L.) namnażanej w kulturach in vitro

\begin{tabular}{|c|c|c|c|}
\hline $\begin{array}{l}\text { Medium } \\
\text { Pożywka }\end{array}$ & $\begin{array}{c}\text { Chl a } \\
{\left[\mathrm{mg} \cdot \mathrm{g}^{-1} \mathrm{fw}\right]}\end{array}$ & $\begin{array}{c}\mathrm{Chl} \mathrm{b} b \\
{\left[\mathrm{mg} \cdot \mathrm{g}^{-1} \mathrm{fw}\right]}\end{array}$ & $\begin{array}{c}\text { Car } \\
{\left[\mathrm{mg} \cdot \mathrm{g}^{-1} \mathrm{fw}\right]}\end{array}$ \\
\hline MS & $51.45 b^{*}$ & $29.96 \quad b$ & 18.73 \\
\hline $\mathrm{MS}+1 \mathrm{mM}$ ASA & $54.12 \quad a$ & $30.59 a$ & 21.01 \\
\hline $\mathrm{MS}+1 \mathrm{Mm} \mathrm{Pb}\left(\mathrm{NO}_{3}\right)_{2}$ & 40.63 & $14.67 \mathrm{~d}$ & 8.64 \\
\hline $\mathrm{MS}+1 \mathrm{mM} A S A+1 \mathrm{mM} \mathrm{Pb}\left(\mathrm{NO}_{3}\right)_{2}$ & 45.95 & 21.94 & 14.40 \\
\hline Mean - Średnia & 48.03 & 24.29 & 15.69 \\
\hline
\end{tabular}

Explanations see Table 1 - Objaśnienia zob. tab. 1. 
Addition to MS medium $1 \mathrm{mM}$ ASA under heavy metal stress markedly increased $\mathrm{Chl}$ a and $\mathrm{Chl} b$ and Car content by $13 \%(\mathrm{Chl} \mathrm{a}), 49 \%(\mathrm{Chl} \mathrm{b})$ and $67 \% \mathrm{Car}$ ) compared with $\mathrm{Pb}$ alone treatment. Moreover, it was observed that application of $1 \mathrm{mM}$ ASA alone significantly increased photosynthetic ( $\mathrm{Chl} a$ and $\mathrm{Chl} b$ ) and nonphotosynthetic (Car) pigments contents compared with those in the control (Table 3). A negative influence of heavy metal stress on chlorophylls concentration in wheat and spinach plants was observed by Lamhamdi et al. (2013). Authors showed that concentrations of chlorophylls $a$ and $b$ were already significantly lower at $1.5 \mathrm{mM} \mathrm{Pb}$, and this effect was more pronounced at 3 and $15 \mathrm{mM} \mathrm{Pb}$. Similar result was obtained by Akinci et al. (2010) in tomato who found that $\mathrm{Chl} a$ and $b$ and $a+b$ was significantly affected by increasing lead concentration $\left(0-300 \mathrm{mg} \cdot \mathrm{dm}^{-3}\right)$.

According to many authors (Agami 2014; Hussein and Alva 2014; Krupa-Małkiewicz et al. 2015) the exogenous application of biologically active substances such as ascorbic acid is effective in mitigating the adverse effects of salt stress on growth of many plants. In addition, Cao et al. (2013) showed that Cd-induced chlorophyll synthesis inhibition was markedly reverted and the content was even more than control when rice seedlings were pre-treated with GSH, GB or SA.

Effects of lead on proline and MDA content. In opinion of many authors (Lamhamdi et al. 2011; Yang et al. 2011; Cao et al. 2013; Krupa-Małkiewicz et al. 2015) elevated proline and MDA levels in plant tissue are quite good indicators of the negative effects of various stress factors on a plant. Excessive proline accumulation occurs as a strong reaction of environmental stress, which results from its uncontrolled biosynthesis, limited oxidation, inhibition of its incorporation into proteins and even release from proteins due to proteolysis (Girija et al. 2002). Measurement of malondialdehyde (MDA) level is routinely used as an index of lipid peroxidation under stressful conditions (Yang et al. 2011; Cao et al. 2013).

In this study, the contents of proline in goji seedlings was significantly increased (3.51 $\mu \mathrm{mol} \cdot \mathrm{g}^{-1} \mathrm{fm}$ and $4.56 \mu \mathrm{mol} \cdot \mathrm{g}^{-1} \mathrm{fm}$, respectively) when $1.0 \mathrm{mM} \mathrm{ASA}$ or $1.0 \mathrm{mM} \mathrm{Pb}\left(\mathrm{NO}_{3}\right)_{2}$ were used in comparison to the control $\left(1.88 \mu \mathrm{mol} \cdot \mathrm{g}^{-1} \mathrm{fm}\right)-$ Table 4.

Table 4. The influence of $1 \mathrm{mM}$ ascorbic acid and $1 \mathrm{mM} \mathrm{Pb}\left(\mathrm{NO}_{3}\right)_{2}$ on proline and MDA in leaves of goji (Lycium barbarum L.) in in vitro culture

Tabela 4. Wpływ $1 \mathrm{mM}$ kwasu askorbinowego i $1 \mathrm{mM} \mathrm{Pb}\left(\mathrm{NO}_{3}\right)_{2}$ na zawartość proliny i MDA w liściach goji (Lycium barbarum L.) namnażanej w kulturach in vitro

\begin{tabular}{lccrl}
\hline \multicolumn{1}{c}{$\begin{array}{c}\text { Medium } \\
\text { Pożywka }\end{array}$} & $\begin{array}{c}\text { Proline } \\
{\left[\mu \mathrm{ml} \cdot \mathrm{g}^{-1} \mathrm{fw}\right]}\end{array}$ & $\begin{array}{c}\text { MDA } \\
{\left[\mathrm{nmol} \cdot \mathrm{g}^{-1} \mathrm{fw}\right]}\end{array}$ \\
\hline $\mathrm{MS}$ & 1.88 & $\mathrm{~d}^{*}$ & 7.69 & $\mathrm{~d}$ \\
\hline $\mathrm{MS}+1 \mathrm{mM} \mathrm{ASA}$ & 3.51 & $\mathrm{c}$ & 9.53 & $\mathrm{c}$ \\
\hline $\mathrm{MS}+1 \mathrm{Mm} \mathrm{Pb}\left(\mathrm{NO}_{3}\right)_{2}$ & 4.56 & $\mathrm{a}$ & 11.22 & $\mathrm{a}$ \\
\hline $\mathrm{MS}+1 \mathrm{mM} \mathrm{ASA}+1 \mathrm{mM} \mathrm{Pb}\left(\mathrm{NO}_{3}\right)_{2}$ & 3.7 & $\mathrm{~b}$ & 10.8 & $\mathrm{~b}$ \\
\hline Mean - Średnia & 5.91 & 9.81 & \\
\hline
\end{tabular}

Explanations see Table 1- Objaśnienia zob. tab. 1.

However, addition to MS medium $1 \mathrm{mM}$ ASA under heavy metal stress decreased proline content by $19 \%$, compared with $\mathrm{Pb}$ alone treatment. These results confirm the finding of Azooz et. al (2013) who reported that most of the vitamins tend to increase the proline content 
under stress factor. Similar response to $\mathrm{Pb}$ treatment was previously noticed in bean (Zengin and Munzuroglu 2005), wheat (Yang et al. 2011), and in various plants species (Sędzik et. al 2015). Lamhamdi et al. (2011) observed that proline concentrations increase with those of lead in the growth medium, and this increase is more relevant in roots than in coleoptiles.

In the present study, $\mathrm{Pb}$ stress induced oxidative stress characterized significant increase in MDA content by $46 \%$ compare with control (Table 4). It may be suggest that more MDA accumulation could account for presence of the poisoning reactive oxygen species (ROS). Addition to MS medium $1 \mathrm{mM}$ ASA with $1 \mathrm{mM} \mathrm{Pb}\left(\mathrm{NO}_{3}\right)_{2}$ decreased MDA content by $4 \%$ in goji seedlings compared with $\mathrm{Pb}$ alone treatment. However, in comparison with the control, $1 \mathrm{mM}$ ASA alone treatment induced $24 \%$ more MDA accumulation in goji seedlings, over the control. Najeeb et al. (2017) reported that since lipid peroxidation is a biochemical marker for stress-induced damage in plants, elevated MDA level under lead indicated that $\mathrm{Pb}$ toxicity induced oxidative damage to Juncus effusus L. Lead induced lipid peroxidation has already been reported in wheat (Lamhamdi et al. 2011; Yang et al. 2011). In turn, Qiao et al. (2015) observed that significant accumulation of $\mathrm{Pb}$ resulted in oxidative stress in Potamogeton crispus L. but it was efficiency controlled. The role of biologically active substances in modifying the environmental stresses induced changes in osmoprotectant contents was also investigated by Boroumand Jazi et al. (2011), Cao et al. (2013) and Krupa-Małkiewicz et al. (2015). According to Krupa-Małkiewicz et al. (2015) ascorbic acid may be of value within biotechnology for the production of valuable substances as well as plant protection. This vitamin might act as activators of protein synthesis through modulating the activity of enzymes involved in the metabolism of proteins or sugars.

\section{CONCLUSION}

It is obvious from our results that lead treatment even at low concentration (1 $\mathrm{mM})$ induced large disturbances in plant growth, especially shoot and root length. Heavy metal stress had negative influence on biochemical parameters such as proline, MDA, chlorophylls and carotenoid. However, application of $1 \mathrm{mM}$ ascorbic acid as an antioxidant compound increased apical growth as well as development and biochemical parameters of Lycium barbarum L. in in vitro culture.

\section{REFERENCES}

Abdelhamid M.T., Sadak M.S.H., Schmidhalter U.R.S., El-Saady M. 2013. Interactive effects of salinity stress and nicotinamide on physiological and biochemical parameters of faba bean plant. Acta Biol. Colomb. 18(3), 499-510.

Akinci I.E., Akinci S., Yilmaz K. 2010. Response of tomato (Solanum lycopersicum L.) to lead toxicity: growth, element uptake, chlorophyll and water content. Afr. J. Agric. Res. 5, 416-423.

Agami R.A. 2014. Applications of ascorbic acid or proline increase resistance to salt stress in barley seedlings. Biol. Plant. 58(2), 341-347.

Arnon D.J., Allen M.B., Whatley F. 1956. Photosynthesis by isolated chloroplast. Biochim. Biophys. Acta 20, 449-461. 
Azooz M.M., Alzahrani A.M. Youssef M.M. 2013. The potential role of seed priming with ascorbic acid and nicotinamide and their interactions to enhance salt tolerance in broad bean (Vicia faba L.). Aust. J. Crop. Sci. 7, 2091-2100.

Bates L.S., Waldren R., Teare I. 1973. Rapid determination of free proline for water-stress studies. Plant Soil 39(1), 205-207.

Boroumand Jazi Sh., Lari Yazdi H., Ranjbar M. 2011. Effects of salicylic acid on some plant growth parameters under lead stress in Brassica napus var. Okapi. Iranian J. Plant Physiol. 1(3), 177-185.

Bybordi A. 2012. Effect of ascorbic acid and silicium on photosynthesis, antioxidant enzyme activity, and fatty acid contents in canola exposure to salt stress. J. Integr. Agric. 11, 1610-1620.

Cao F., Liu L., Ibrahim W., Cai Y., Wu F. 2013. Alleviating effects of exogenous glutathione, glycinebetaine, brassinosteroids and salicylic acid on cadmium toxicity in rice seedlings (Oryza sativa). Agrotechnol. 2, 107. DOI:10.4172/2168-9881.1000107.

Dimitrova V., Georgieva T., Markovska Y. 2016. Influence of salt stress on some physiological characteristics of two Lycium varieties grown ex vitro in hydroponics. Youth Scientific Conference Kliment's Days. Sofia 101(4), 141-148.

Girija C., Smith B.N., Swamy P.M. 2002. Interactive effects of sodium chloride and calcium chloride on the accumulation of proline and glycinebetaine in peanut (Arachis hypogaea L.). Environ. Exp. Bot. 47, 1-10.

Hassanein R.A., Bassuony F.M., Baraka D.M., Khalil R.R. 2009. Physiological effects of nicotinamide and ascrobic acid on Zea mays plant grown under salinity stress. 1-changes in growth, some relevant metabolic activities and oxidative defense systems. Res. J. Agric. Biol. Sci. 5(1), 72-81.

Hendry G.A.F., Grime J.P. 1993. Methods in comparative plant ecology. New York, Marcel Dekker Inc.

Hussein M.M., Alva A.K. 2014. Effects of zinc and ascorbic acid application on the growth and photosynthetic pigments of millet plants grown under different salinity. Agric. Sci. 5, 1253-1260.

Krupa-Małkiewicz M., Smolik B., Ostojski D., Sędzik M. 2015. Effect of ascorbic acid on morphological and biochemical parameters in tomato seedling exposure to salt stress. Environ. Protect. Nat. Res. 24(2), 25-27.

Lamhamdi M., Bakrim A., Aarab A., Lafont R., Sayah F. 2011. Lead phytotoxicity on wheat (Triticum aestivum L.) seed germination and seedlings growth. C. R. Biol. 334, 118-126.

Lamhamdi M., El Galiou O., Bakrim A., Nóvoa-Muñoz J.C., Arias-Estévez M., Aarab A., Lichtenthaler H.K, Wellburn A.R. 1983. Determinations of total carotenoids and chlorophylls a and $b$ of leaf extracts in different solvents. Biochem. Soc. Trans. 11, 591-592.

Munns R. 2005. Genes and salt tolerance: bringing them together. New Phytol. 167, 645-663.

Murashige T., Skoog F. 1962. A revised medium, for rapid growth and bioassays with tobacco tissue cultures. Physiol. Plant. 15(3), 473-479.

Nagajyoti P.C., Lee K.D., Sreekanth T.V.M. 2010. Heavy metals, occurrence and toxicity for plants: a review. Environ. Chem. Lett. 8, 199-216.

Najeeb U., Ahmad W., Zia M.H., Malik Z., Zhou W. 2017. Enhancing the lead phytostabilization in wetland plant Juncus effuses L. through somaclonal manipulation and EDTA enrichment. Arabian J. Chem. 10, 3310-3317.

Nowakowska M., Ochmian I., Mijowska K. 2017. The influence of street conditions on sea buckthorn fruit quality and content of micro- and macronutrients in berries and in soil. J. Elem. 22(1), 235-244

Piwowarczyk B., Tokarz K., Kamińska I. 2016. Responses of grass pea seedlings to salinity stress in in vitro culture conditions. Plant Cell. Tiss. Organ Cult. 124(2), 227-240.

Price A.H., Hendry G.A. 1991. lon-catalyzed oxygen radical formation and its possible contribution to drought damages in nine native grasses and three cereals. Plant Cell Environ. 14(5), 477-484.

Qiao X., Zheng Z., Zhang L., Wang J., Shi G., Xu X. 2015. Lead tolerance mechanism in sterilized seedlings of Potamogeton crispus L.: Subcellular distribution, polyamines and proline. Chemosphere 120, 179-187. 
Ruley A.T., Sharma N.C., Sahi S.V. 2004. Antioxidant defense in lead accumulating plant, Sesbania drummondii. Plant Physiol. Biochem. 42, 899-906.

Sadak M.S.H., Abdelhamid M.T., El-Saady M. 2010. Physiological responses of faba bean plant to ascorbic acid grown under salinity stress. Egyptian J. Agronom. 32(1), 89-106.

Sędzik M., Smolik B., Krupa-Małkiewicz M. 2015. Effect of lead on germination and some morphological and physiological parameters of 10-day-old seedlings of various plant species. Environ. Protect. Natur. Res. 26(3), 22-27.

Sharma P., Dubey R. 2005. Lead toxicity in plants. Brazilian J. Plant Physiol. 17, 35-52.

Sudhakar C., Lakshim A., Giridarakumar S. 2001. Changes in the antioxidant enzyme efficacy in two high yielding genotypes of mulberry (Morus alba L.) under $\mathrm{NaCl}$ salinity. Plant Sci. 161(3), 613-619.

Tuna A.L., Kaya C., Dikilitas M., Higgs D.E.B. 2008. The combined effects of gibberellic acid and salinity on some antioxidant enzyme activities, plant growth parameters and nutritional status in maize plants. Environ. Exp. Bot. 62(1), 1-9.

Yang Y., Zhang Y., Wei X., You J., Wang W., Lu J., Shi R. 2011. Comparative antioxidative responses and proline metabolism in two wheat cultivars under short term lead stress. Ecotox. Environ. Saf. 74, 733-740.

Younis M.E., Hasaneen M.N.A., Kazamel A.S. 2010. Exogenously applied ascorbic acid ameliorates detrimental effects of $\mathrm{NaCl}$ and mannitol stress in Vicia faba seedlings. Protoplasma 239(1), 39-48.

Zengin F.K., Munzuroglu O. 2005. Effects of some heavy metals on content of chlorophyll, proline and some antioxidant chemicals in bean (Phaseolus vulgaris L.) seedlings. Acta Biol. Cracov. Series Botanica 47(2), 157-164

Zheng J., Ding C.X., Wang L.S., Li G.L., Shi J.Y., Li H., Wang H.L., Suo Y.R. 2011. Anthocyanins composition and antioxidant activity of wild Lycium ruthenicum Murr. from Qinghai-Tiber plateau. Food Chem. 126, 859-865.

Abstract. Lead $(\mathrm{Pb})$ is the most common heavy metal pollutant in the environment. The objective of the presented study was to investigate the ameliorative effect of exogenous $1 \mathrm{mM}$ ASA on key growth and biochemical parameters in Lycium barbarum seedlings under heavy metal $\left(\mathrm{Pb}\left(\mathrm{NO}_{3}\right)_{2}\right)$ stress in vitro. Nodal cutting with an axillaries bud were used as an explants. The results showed that lead accumulation in goji explants had negative influence on morphological parameters of plant growth, such as shoot and root length. Lead caused a significant reduction in chlorophylls and carotenoid content, increased lipid peroxidation and induced significant accumulation of proline in goji leaves. Addition to MS medium $1 \mathrm{mM}$ ASA greatly alleviated $\mathrm{Pb}$-induced growth inhibition and $\mathrm{Pb}$-induced MDA and proline accumulation. Presence of ASA in the MS medium under heavy metal stress increased plant fresh and dry mass with no significant effect on plant water content. 